\title{
PDZ Domain
}

National Cancer Institute

\section{Source}

National Cancer Institute. PDZ Domain. NCI Thesaurus. Code C133734.

A g lobular protein domain of 80 to 90 amino acids comprising six beta-strands and two alpha-helices that plays a role in anchoring receptor proteins in the membrane to cytoskeletal components. 